\title{
Divalent Cations in the Envelope of a Psychrophilic Achromobacter
}

\author{
By INGRID LEDEBO \\ Department of Microbiology, University of Lund, Sölvegatan 2I, S-223 62 Lund, Sweden
}

(Received 2 October 1975; revised 12 December 1975)

\begin{abstract}
SUMMARY
The function of $\mathrm{Ca}^{2+}$ in a psychrophilic Achromobacter, previously found to bind large amounts of these ions to its envelope, has been studied. Bacteria suspended in media of low ionic content showed decreases in wet weight, dry weight and growth capacity, and increases in light scattering and in the release of u.v.absorbing substances into the medium. The permeability barrier to $\mathrm{Ca}^{2+}$ was also damaged, and there was a release of radioactivity from bacteria labelled with ${ }^{45} \mathrm{Ca}^{2+}$. These events occurred at the optimum growth temperature, and took place at increased rates at higher temperatures. Damage was prevented to about the same extent by $0 \cdot 1 \mathrm{mM}-\mathrm{CaCl}_{2}, \mathrm{BaCl}_{2}$ or $\mathrm{MgCl}_{2}$ and by $10 \mathrm{~mm}-\mathrm{NaCl}, \mathrm{KCl}$ or $\mathrm{LiCl}$. Ion competition experiments showed that $\mathrm{Ca}^{2+}$ was preferentially taken up and retained in comparison with $\mathrm{Ba}^{2+}, \mathrm{Mg}^{2+}$ and $\mathrm{Na}^{+}$, in that order. Isolated envelopes gave similar results. The dry weight of envelopes was reduced by $35 \%$ when they were suspended in water at $40^{\circ} \mathrm{C}$.

It is clear that the function of certain envelope components in Achromobacter is highly dependent on divalent cations; and that both the integrity of the permeability barrier and the stability of the envelope are affected at low ion concentrations.
\end{abstract}

\section{INTRODUCTION}

Divalent cations have been assigned several important roles in the envelopes of Gramnegative bacteria. By joining adjacent negative groups they affect the structure and function of the various envelope layers. In the outer membrane of the envelope, divalent cations may provide association between some lipopolysaccharide molecules (Nikaido, 1973; Leive, 1974). Crosslinking by $\mathrm{Mg}^{2+}$ in the peptidoglycan molecule may contribute to the mechanical strength of this component (Rayman \& MacLeod, 1975); and the integrity of lipidprotein membranes depends on divalent cations (Brown, I964; Hendricks, I964; Reynolds, 1972).

An earlier publication (Ledebo, 1974) described the uptake of $\mathrm{Ca}^{2+}$ by a psychrophilic Achromobacter strain at sites mainly outside the permeability barrier, i.e. in the envelope. The amount of $\mathrm{Ca}^{2+}$ taken up greatly exceeded that reported for other Gram-negative bacteria such as Rhizobium trifolii (Humphrey \& Vincent, 1962) and Pseudomonas aeruginosa (Eagon, Simmons \& Carson, 1965). Thus, studies of Achromobacter may throw additional light on the function of divalent cations in Gram-negative envelopes. The object of this investigation was to determine the effect of low cation concentrations on the integrity of the Achromobacter; and to study the cation-binding specificity of isolated bacterial envelopes.

\section{METHODS}

Preparation of bacterial suspensions. Achromobacter no. 102, a psychrophilic laboratory strain (Ledebo \& Ljunger, I973), was grown in $1 \%$ Bacto-peptone (Difco) at $20^{\circ} \mathrm{C}$ in a shaking water bath until the bacteria reached the mid-exponential phase of growth $(0.1 \mathrm{I} \mathrm{mg}$ 
dry $w t / m l$ ). Bacteria were harvested by centrifuging, washed once in deionized water, suspended in water and kept at $0{ }^{\circ} \mathrm{C}$ until the start of the experiment. All suspensions were prepared on the day of use.

Preparation of envelopes. Bacteria were harvested during the exponential phase of growth, one generation later than indicated above. They were washed once in $\mathrm{I} \mathrm{mM}_{-} \mathrm{CaCl}_{2}$ and disintegrated in a Ribi Cell Fractionator (Sorvall) at $25000 \mathrm{lbf}^{-\mathrm{ln}^{-2}}$. To separate intact cells, the treated suspension was centrifuged at $2700 \mathrm{~g}$ for $20 \mathrm{~min}$ at $2{ }^{\circ} \mathrm{C}$. The supernatant was further centrifuged at $25000 \mathrm{~g}$ for $20 \mathrm{~min}$ to sediment the envelopes. These were washed three times in $1 \mathrm{~mm}^{-\mathrm{CaCl}_{2}}$ and finally suspended in $1 \mathrm{~mm}-\mathrm{CaCl}_{2}$ to about $6 \mathrm{mg}$ dry $\mathrm{wt} / \mathrm{ml}$. The suspension was divided into portions and frozen.

Radioactivity exposure and measurement. The radioisotope ${ }^{45} \mathrm{Ca}^{2+}$ (from The Radiochemical Centre, Amersham, Buckinghamshire) was added to an aqueous solution of peptone or salt; and the resulting radioactive solution was mixed with either a volume of the bacterial suspension, a heat-treated bacterial pellet, or a sample of envelopes. Samples corresponding to about $20 \mathrm{mg}$ dry cells or $3 \mathrm{mg}$ dry envelopes were normally used. Exposure to the isotope took place at room temperature (approximately $20^{\circ} \mathrm{C}$ ) for $\mathrm{I}$ h. The cells or envelopes were then separated by centrifuging at $2{ }^{\circ} \mathrm{C}$, the supernatant was poured off rapidly, and any remaining fluid blotted away from the interior of the centrifuge tube. The entire pellet, which contained only the envelopes or cells and unavoidable extracellular fluid, was used for subsequent experiments or for radioactivity measurements.

The pellet was suspended in $0.5 \mathrm{ml} 0.5 \%$ peptone and the suspension mixed with scintillation liquid $(10 \mathrm{ml})$ and transferred to a vial. The scintillation liquid contained $100 \mathrm{~g}$ naphthalene and $8 \mathrm{~g}$ butyl-PBD [2-(4'-t-butylphenyl)-5-(4'-biphenyl)-I,3,4-oxadiazole] dissolved in 11 dioxan: all chemicals were scintillation grade. To eliminate chemiluminescence, vials were kept in the dark for $\mathrm{I} h$ before the radioactivity was counted in a liquid scintillation counter ( $\beta$-Mate II, Beckman Instruments) for three I min periods. The counting efficiency was about $75 \%$ as determined by the internal standard method. The radioactivity of the supernatant liquid was measured on $0.5 \mathrm{ml}$ samples.

Measurement of light scattering. An EEL nephelometer head on an EEL Unigalvo Type 20 was used for recording the light scattering of bacterial suspensions. The values were related to a predetermined standard, the assigned unit being the same for all experiments.

Weight determination. After removing the residual medium, the wet weight of the cell pellet was determined. Dry weights were determined after heating overnight at $105{ }^{\circ} \mathrm{C}$.

\section{RESULTS}

When washed Achromobacter organisms were suspended in water, the light-scattering capacity of the suspension remained constant at $0{ }^{\circ} \mathrm{C}$ but increased with increase in temperature (Fig. 1). Yet if calcium ions were added to the suspending medium there was no such increase in light scattering with temperature (Fig. $7 b$ ). Increased light scattering which could not be attributed to increases in bacterial numbers may be due to volume reductions of the cells (Kcch, 196I). Thus, the relationship between the wet weight and the nephelometer value of cells suspended in water and treated at 25 and $35^{\circ} \mathrm{C}$ was studied (Fig. 2). The increase in light scattering correlated closely with decrease in wet weight. The dry weight was practically unchanged at $25{ }^{\circ} \mathrm{C}$ and decreased by only about $15 \%$ at $35{ }^{\circ} \mathrm{C}$. Thus, the decrease in wet weight of the organisms was mainly due to loss of cell water.

The leakage of intracellular components was studied by measuring the u.v.-absorption of the surrounding medium (Fig. 3). Leakage was detected when the cells were suspended 


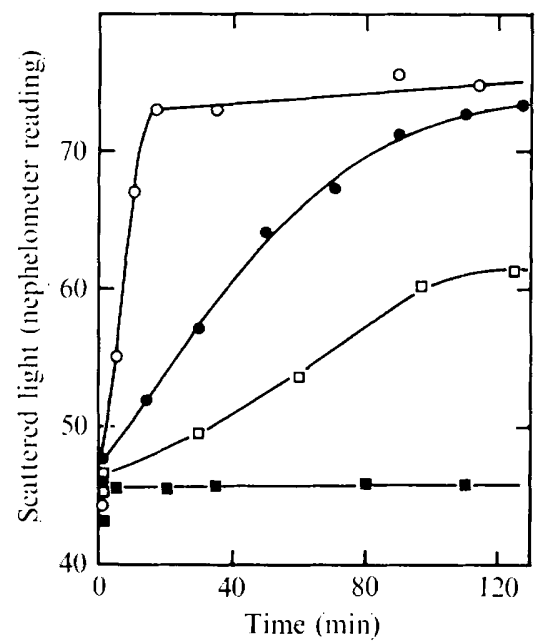

Fig. I

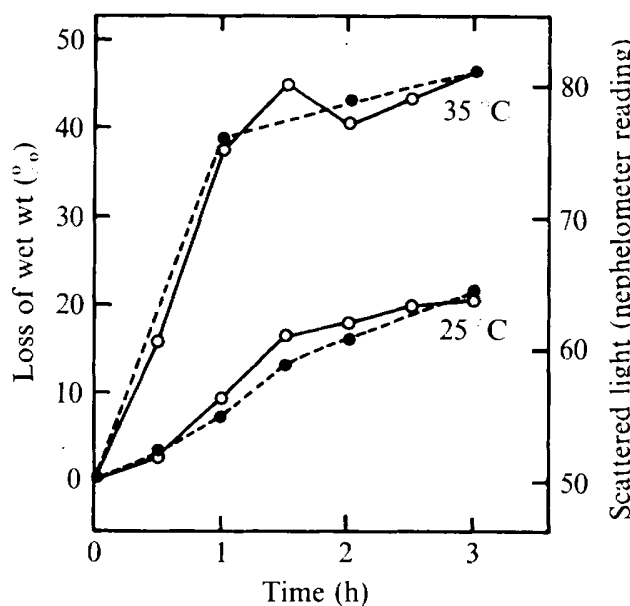

Fig. 2

Fig. I. The light-scattering capacity of Achromobacter cells suspended in water at $0^{\circ} \mathrm{C}(\square)$, $10{ }^{\circ} \mathrm{C}(\square), 25^{\circ} \mathrm{C}(0)$ and $40^{\circ} \mathrm{C}(\mathrm{O})$. Concentrated cell suspension in water $(0.5 \mathrm{ml})$ was added to temperature-equilibrated test tubes containing $9.5 \mathrm{ml}$ water and the nephelometer values recorded.

Fig. 2. Changes of wet weight (O) and light scattering $(O)$ of Achromobacter suspended in water at 25 and $35^{\circ} \mathrm{C}$. A bacterial suspension in water ( $1 \mathrm{mg}$ dry wt $/ \mathrm{ml}$ ) was treated at the temperatures stated. Samples $(10 \mathrm{ml})$ were centrifuged at intervals and the pellets weighed. Other samples ( $\cdot \circ \mathrm{ml})$ were diluted in $9 \mathrm{ml}$ water and the light scattering measured. The values of weight and light scattering at $35^{\circ} \mathrm{C}$ were adjusted so that they coincided at zero time and after $3 \mathrm{~h}$ and corresponding adjustments were made to all other values.

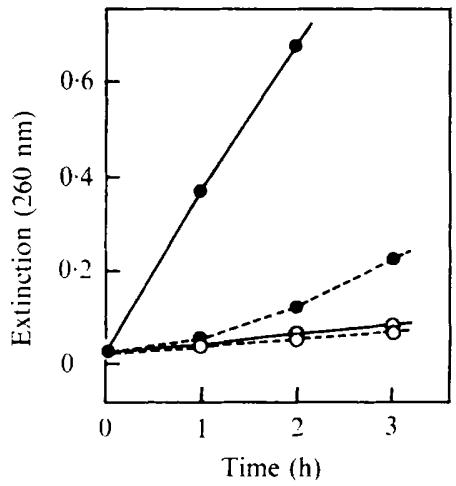

Fig. 3

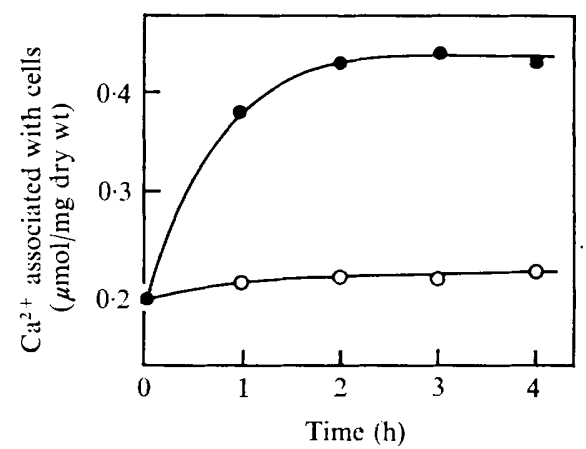

Fig. 4

Fig. 3. Release of u.v.-absorbing substances from Achromobacter in water (O) and in $10 \mathrm{~mm}$ $\mathrm{CaCl}_{2}(\mathrm{O})$ at $25{ }^{\circ} \mathrm{C}$ (dashed lines) and $35^{\circ} \mathrm{C}$ (full lines). A suspension (I mg dry wt/ml) was treated as indicated and the u.v.-absorption of the supernatant was measured at $260 \mathrm{~nm}$.

Fig. 4. Uptake of $\mathrm{Ca}^{2+}$ by Achromobacter after treatment in water (O) and in $10 \mathrm{mM}-\mathrm{CaCl}_{2}(\mathrm{O})$ at $35^{\circ} \mathrm{C}$ for various times, followed by exposure to $10 \mathrm{~mm}-{ }^{45} \mathrm{CaCl}_{2}$.

in water at 25 and $35^{\circ} \mathrm{C}$, but was insignificant in $10 \mathrm{mM}-\mathrm{CaCl}_{2}$ at these temperatures. No lysis was seen microscopically.

When the permeability barrier of Achromobacter is destroyed with, for example, toluene, the uptake of calcium ions increases greatly (Ledebo, 1974). This was interpreted as indi- 


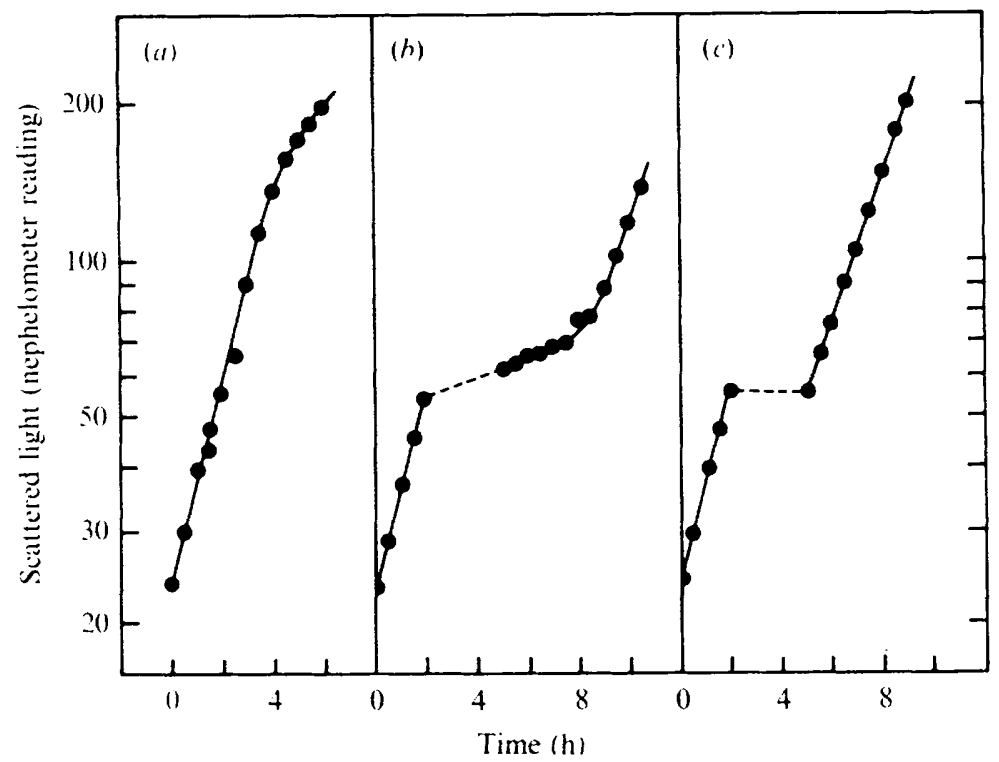

Fig. 5. Growth of Achromobacter in peptone at $25^{\circ} \mathrm{C}(a)$. After $2 \mathrm{~h}$ exponential growth, the bacteria were separated from the medium, washed, suspended in water $(b)$ or $1 \mathrm{mM}-\mathrm{CaCl}_{2}(c)$, and incubation was continued. After another $2 \mathrm{~h}$ the bacteria were resuspended in their original growth medium and reincubated.

cating that in untreated organisms, calcium ions are bound mainly to the envelope, whereas in leaky cells the ions also gain access to the cell interior. On this basis, the protective effect of calcium ions on the permeability barrier of Achromobacter was examined. The calcium uptake of bacteria which had been treated in water at $35^{\circ} \mathrm{C}$ increased with increasing duration of the heat treatment (Fig. 4). However, when the same heat treatment was done in $10 \mathrm{mM}-\mathrm{Ca}^{2+}$, the uptake of $\mathrm{Ca}^{2+}$ remained constant, indicating an unaffected permeability barrier.

These observations suggested that water treatment at $35^{\circ} \mathrm{C}$ greatly damaged the Achromobacter. In $\mathrm{I} \%$ peptone, $35^{\circ} \mathrm{C}$ is above the maximum growth temperature and reduces survival to about $30 \%$ after $2 \mathrm{~h}$. The optimum growth temperature is approximately $25^{\circ} \mathrm{C}$ and growth capacity after treatment in water and $\mathrm{I} \mathrm{mM}-\mathrm{CaCl}_{2}$ at this temperature is shown in Fig. 5. After suspension in I mM-CaCl 2 for $2 \mathrm{~h}$ at $25^{\circ} \mathrm{C}$, the bacteria resumed exponential growth immediately, whereas suspension in water for the same time markedly reduced the growth rate during the following $3 \mathrm{~h}$.

It was shown in several experiments that $\mathrm{Ca}^{2+}$ in the suspending medium prevented certain types of damage to Achromobacter. The large capacity of envelopes for binding $\mathrm{Ca}^{2+}$ is probably responsible for the protective effect of the ionic solutions. However, even before suspension in $\mathrm{Ca}^{2+}$ solution, the cells contained $\mathrm{Ca}^{2+}$ taken up during growth, since the growth medium contained 0.05 to $0.1 \mathrm{mM}-\mathrm{Ca}^{2+}$. The following experiment demonstrated what happened to the $\mathrm{Ca}^{2+}$ bound to the envelope during growth, when the cells were suspended in water.

The cells were labelled with radioactive calcium in $0.5 \%$ peptone so that the $\mathrm{Ca}^{2+}$ concentration did not exceed that of the normal growth medium. During treatment in water at 25 or $40^{\circ} \mathrm{C}$, the cells gradually released radioactivity into the medium (Fig. 6). At $40^{\circ} \mathrm{C}$ a maximum of about $35 \%$ was reached within $2 \mathrm{~h}$ and was still maintained after $24 \mathrm{~h}$. At $25{ }^{\circ} \mathrm{C}$, the release was slower, being about $25 \%$ after $24 \mathrm{~h}$. At $0^{\circ} \mathrm{C}$, the release of radio- 


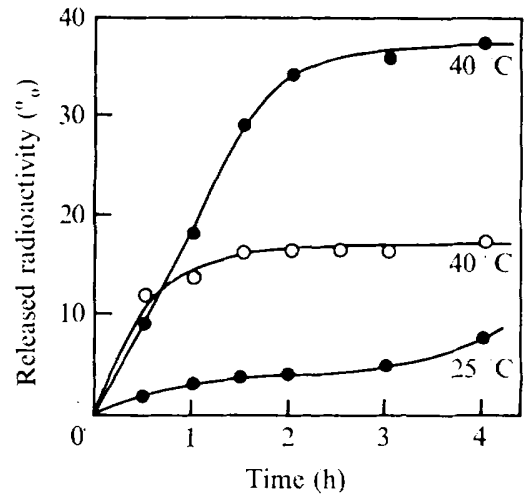

Fig. 6. Release of radioactivity from Achromobacter cells (O) and envelopes ( $O$ ). Cells and envelopes were labelled with ${ }^{45} \mathrm{CaCl}_{2}$ in peptone, washed, and suspended in water at 25 and $40{ }^{\circ} \mathrm{C}$ at densities of $\mathrm{r} \mathrm{mg}$ dry cells $/ \mathrm{ml}$ or $0.6 \mathrm{mg}$ dry envelopes $/ \mathrm{ml}$. Samples were taken at intervals and the radioactivity of the pellet and of the supernatant measured.

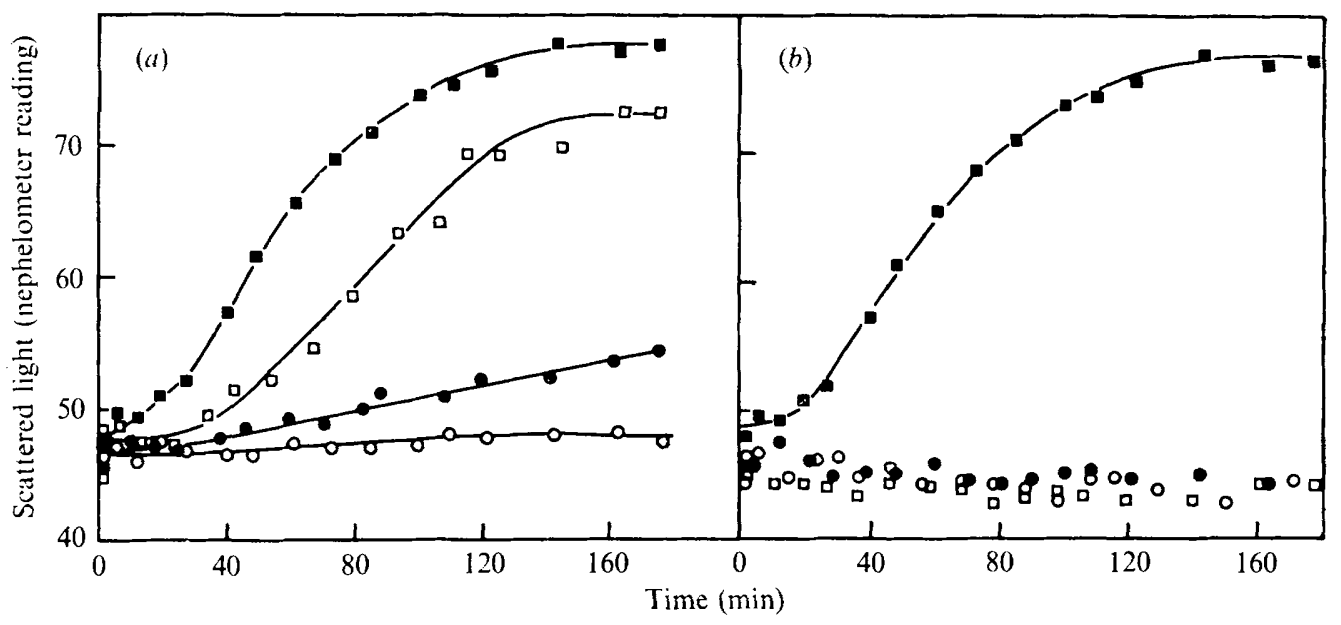

Fig. 7. Light scattering by Achromobacter suspended in solutions of (a) $\mathrm{NaCl}$ and (b) $\mathrm{CaCl}_{2}$ at room temperature. Concentrations of solutions were: $0.1 \mathrm{mM}(\square)$; I $\mathrm{mM}(0)$; IO $\mathrm{mm}(\mathrm{O})$; water

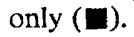

activity was negligible. The released radioactivity could be filtered through Millipore filters with a pore diameter of $0.22 \mu \mathrm{m}$ and dialysed to the same extent as $\mathrm{Ca}^{2+}$ in aqueous solution. This indicated that the released radioactive material consisted of very small moieties, perhaps the calcium ions alone. However, dry weight studies on the treated cells showed reductions of up to $15 \%$ after $2 \mathrm{~h}$ at $40^{\circ} \mathrm{C}$. The loss of internal solutes observed earlier could not account for such large values, so it was assumed that envelope components were released at the same time as the $\mathrm{Ca}^{2+}$. This was confirmed by repeating the experiment with isolated envelopes, which also released radioactivity when suspended in water at $40{ }^{\circ} \mathrm{C}$ (Fig. 6). The maximum release of radioactivity, about $17 \%$, was reached within $2 \mathrm{~h}$ and was only slightly higher after $24 \mathrm{~h}$ at $40^{\circ} \mathrm{C}$. The dry weight of the envelopes was reduced by about $15 \%$ after $2 \mathrm{~h}$ at $40{ }^{\circ} \mathrm{C}$ but continued to decrease and, after $24 \mathrm{~h}$, about $35 \%$ of the envelope dry matter had been released into the medium.

In the above experiments, only $\mathrm{Ca}^{2+}$ had been used. However, other inorganic cations 
Table 1. Exchange between $\mathrm{Ca}^{2+}$ bound to intact Achromobacter and to envelopes and other ions in the medium

Samples were first exposed to $1 \mathrm{mM}^{45} \mathrm{CaCl}_{2}$, then centrifuged and the pellet suspended in the various ionic solutions ( $\mathrm{I} \mathrm{mm}$ ). Exchange of ions was calculated from the released radioactivity.

\begin{tabular}{|c|c|c|}
\hline \multirow[b]{2}{*}{ Suspending medium } & \multicolumn{2}{|c|}{ Exchange $(\%)^{*}$ with $\mathrm{Ca}^{2}$} \\
\hline & Bacteria & Envelopes \\
\hline $\mathrm{CaCl}_{2}$ & $100 \cdot 0$ & $100 \cdot 0$ \\
\hline $\mathrm{BaCl}_{2}$ & 78.0 & 94.9 \\
\hline $\mathrm{MgCl}_{2}$ & $73 \cdot 6$ & $62 \cdot 9$ \\
\hline $\mathrm{NaCl}$ & $31 \cdot 7$ & $26 \cdot 1$ \\
\hline
\end{tabular}

Table 2. Competitive binding of $\mathrm{Ca}^{2+}$ and other ions to intact cells and envelopes of Achromobacter

The cells and envelopes were exposed to the ionic solutions for $\mathrm{I} h$ at room temperature and the uptake of ${ }^{45} \mathrm{Ca}^{2+}$ was measured. Solutions were $0.5 \mathrm{~mm}$ except where indicated.

$\begin{array}{ccc}\text { Suspending medium } & \overbrace{\text { Bacteria }}^{\text {Radioactivity }(\%)^{*}} & \text { Envelopes } \\ { }^{45} \mathrm{CaCl}_{2}(1 \cdot 0 \mathrm{mM}) & 100 \cdot 0 & 100 \cdot 0 \\ { }^{45} \mathrm{CaCl}_{2}+{ }^{40} \mathrm{CaCl}_{2} & 50 \cdot 5 & 48.3 \\ { }^{45} \mathrm{CaCl}_{2}+\mathrm{BaCl}_{2} & 53.8 & 49 \cdot 7 \\ { }^{45} \mathrm{CaCl}_{2}+\mathrm{MgCl}_{2} & 57 \cdot 7 & 55.6 \\ { }^{45} \mathrm{CaCl}_{2}+\mathrm{NaCl} & 8 \mathrm{I} \cdot 0 & 76 \cdot 7 \\ { }^{*} \text { Standard error, } \pm 0.4 .\end{array}$

might be expected to serve a similar function and so various ionic solutions were examined for the capacity to prevent increases in light scattering of a bacterial suspension. Figure 7 shows the light scattering of organisms suspended in $\mathrm{NaCl}$ and $\mathrm{CaCl}_{2}$. Concentrations of Io $\mathrm{mM}$ were needed before the monovalent ions $\mathrm{Na}^{+}, \mathrm{K}^{+}$and $\mathrm{Li}^{+}$fully suppressed th: increase of light scattering at room temperature; whereas the divalent ions $\mathrm{Ca}^{2+}, \mathrm{Mg}^{2+}$ and $\mathrm{Ba}^{2+}$ prevented any such increase even at the lowest concentration studied ( $\left.0.1 \mathrm{mM}\right)$.

To examine the specificity of ion binding, the exchange and competition between calcium jons and ions of barium, magnesium and sodium was studied. Both whole cells and isolated envelopes were used and were found to take up (from I mM- ${ }^{45} \mathrm{Ca}^{2+}$ ) 0.13 and $0.52 \mu \mathrm{mol} \mathrm{Ca}^{2+}$ I mg dry wt, respectively. The $\mathrm{Ca}^{2+}$ taken up by the cells could be completely exchanged with $\mathrm{Ca}^{2+}$ in the medium during a subsequent suspension (Table I). $\mathrm{Ba}^{2+}$ and $\mathrm{Mg}^{2+}$ exchanged with $\mathrm{Ca}^{2+}$ to a lesser extent, and $\mathrm{Na}^{+}$the least. Ion exchange with envelopes was similar. When the bacteria and the envelopes were suspended in a mixture of two cations at equimolar concentration, $\mathrm{Ca}^{2+}$ was taken up preferentially before $\mathrm{Ba}^{2+}$ and $\mathrm{Mg}^{2+}$, in that order, and to a large extent before $\mathrm{Na}^{+}$(Table 2).

\section{DISCUSSION}

When suspended in water or media of low ionic content, Achromobacter underwent several changes which indicated damage to the envelope. Clearly, the permeability barrier was affected, since intracellular components were released, and previously excluded $\mathrm{Ca}^{2+}$ was admitted into the interior of the cells. Although the main permeability barrier of bacteria 
is the cytoplasmic membrane, the outer membrane of Gram-negative organisms has some barrier function (Leive, 1974). Other manifestations of damage to Achromobacter when suspended in water included a much reduced wet weight which, assuming that no cell lysis occurred, is interpreted as arising from a reduced cell volume. This change could also be observed as an increased light-scattering capacity of the suspension. Large volume reductions are known to occur when bacteria become plasmolysed or when the wall of Gram-positive bacteria is exposed to salt solutions (Marquis, 1968). Neither cause could be responsible for the present volume reduction of the Achromobacter cells since they were suspended in pure water. However, a component involved in the mechanical stability of the envelope is probably affected by the treatment, since the large volume reduction observed is not compatible with a rigid envelope structure.

Thus, both the barrier function and the stability function of the envelope were impaired when the cells were suspended in water at 25 to $40^{\circ} \mathrm{C}$. The nature of the damage to the envelope is suggested by the way it can be prevented. $\mathrm{Ca}^{2+}$ in the medium was effective in keeping the permeability barrier intact and also maintained the original light-scattering capacity. Since the presence of $\mathrm{Ca}^{2+}$ preserves the integrity of the envelope, it can be assumed that the absence of this ion causes the damage. Furthermore $\mathrm{Ca}^{2+}$ was released from the envelope into the medium under the damaging conditions. This release was as dependent on temperature as the other damage observed. Bacteria suspended in water at $40{ }^{\circ} \mathrm{C}$ lost about $35 \%$ of their bound $\mathrm{Ca}^{2+}$ as well as dry matter, part of which originated from the envelope. The release of envelope components continued after the maximum release of ions had been reached. It appeared that the release of $\mathrm{Ca}^{2+}$ and envelope components that took place during the first two or three hours of water treatment at $40^{\circ} \mathrm{C}$ was the primary damaging event.

Although $\mathrm{Ca}^{2+}$ is assumed to be bound primarily to the envelope, the release of ${ }^{45} \mathrm{Ca}^{2+}$ from whole cells and isolated envelopes is not fully comparable. It seems that a smaller part of the radioactivity is released from the isolated envelopes. This may be because the envelopes have lost components with high calcium-binding capacity during the isolation procedure. Such a loss is also indicated by the relationship between calcium uptake in whole cells and in isolated envelopes. The dry weight of the Gram-negative envelope is usually considered to be about $15 \%$ of the dry weight of the cell (Salton, 1964). If this is applied to Achromobacter, the calcium-binding capacity of the envelopes is only $60 \%$ of that of the whole cells according to the results for uptake in $\mathrm{I} \mathrm{mM}-\mathrm{CaCl}_{2}$.

The ions and the envelope components in Achromobacter are readily released by suspension in water without addition of a chelating agent. In other terrestrial species, ethylenediaminetetraacetate has to be added to achieve a similar release. In Pseudomonas aeruginosa (Cox \& Eagon, I968), Escherichia coli (Leive, 1968) and Salmonella enteritidis (Chipley \& Edwards, 1972), removal of divalent cations from the envelope has been shown to release lipopolysaccharide and to alter the permeability. Lipopolysaccharide is located in the outer membrane of the Gram-negative envelope, where it seems to be involved in maintaining the envelope's passive barrier function (Nikaido, 1973; Costerton, Ingram \& Cheng, 1974; Leive, 1974). The stability of the envelope may also be dependent on the outer membrane. Leive (1968) and Burman, Nordström \& Bloom (1972) treated E. coli with penicillin under various conditions and concluded independently that the peptidoglycan is not solely responsible for the mechanical stability of the envelope: the state of the outer membrane is also important. The outer membrane is associated with the peptidoglycan through covalent links (Braun \& Sieglin, 1970) and with the cytoplasmic membrane through numerous points of adhesion (Bayer, I968). The latter may exist through ionic interactions (Costerton et al., 
1974). Thus, it seems possible that any damage in the outer membrane may affect the inner envelope layers as well.

In conclusion, divalent cations in Achromobacter envelopes seem to have the function of holding in position certain envelope components which are directly or indirectly involved in maintaining the integrity of the permeability barrier and the mechanical stability of the envelope. These observations agree well with the models of the outer membrane presented by Nikaido (1973) and Leive (1974) in which divalent cations hold part of the lipopolysaccharide molecules in place. Both $\mathrm{Ca}^{2+}$ and $\mathrm{Mg}^{2+}$ may be important for this function, the former being more active in the Achromobacter envelope.

Thanks are due to Drs C. Weibull and S. Ståhl for reading the manuscript and to Mrs I. Stål for skilful technical assistance.

This investigation was financially supported by the Swedish Natural Science Research Council.

\section{REFERENCES}

BAYER, M. E. (1968). Areas of adhesion between wall and membrane of Escherichia coli. Journal of General Microbiology 53, 395-404.

BRAUN, V. \& SiegLiN, U. (1970). The covalent murein-lipoprotein structure of the Escherichia coli cell wall. The attachment site of the lipoprotein on the murein. European Journal of Biochemistry 13, 336-346.

Brown, A. D. (1964). Aspects of bacterial response to the ionic environment. Bacteriological Reviews 28, 296-329.

Burman, L. G., Nordström, K. \& Bloom, G. D. (1972). Murein and the outer penetration barrier of Escherichia coli K12, Proteus mirabilis, and Pseudomonas aeruginosa. Journal of Bacteriology 112, I364I 374 .

Chipley, J. R. \& Edwards, H. M., JR (1972). Permeability increases in cells of Salmonella enteritidis induced by ethylenediaminetetraacetate and temperature treatments. Canadian Journal of Microbiology 18, I803-1807.

Cositerton, J. W., Ingram, J. M. \& Cheng, K. J. (1974). Structure and function of the cell envelope of Gram-negative bacteria. Bacteriological Review's 38, 87-110.

Cox, S. T., JR \& EAGON, R. G. (1968). Action of ethylenediaminetetraacetic acid, tris(hydroxymethyl)aminomethane, and lysozyme on cell walls of Pseudomonas aeruginosa. Canadian Journal of Microbiology 14, 913-922.

EAGON, R. G., Simmons, G. P. \& Carson, J. K. (1965). Evidence for the presence of ash and divalent metals in the cell wall of Pseudomonas aeruginosa. Canadian Journal of Microbiology II, I04I-1042.

HeNDricks, S. B. ( r 964). Salt transport across cell membranes. American Scientist 52, 306-334.

HuMPHREY, B. \& VINCENT, J. M. (1962). Calcium in cell walls of Rhizobium trifolii. Journal of General Microbiology 29, 557-56I.

KocH, A. L. (196I). Some calculations on the turbidity of mitochondria and bacteria. Biochimica et biophysica acta 5x, 429-44I.

LEDEBO, I. (1974). Calcium uptake by a psychrophilic Achromobacter strain. Physiologia plantarum 30, 317-322.

Ledebo, 1. \& Ljunger. C. (1973). Permeability of bacteria to inorganic cations. A comparison between a psychrophilic Achromobacter strain and Escherichia coli. Physiologia plantarum 28, 535-540.

LeIVE, L. (1968). Studies on the permeability change produced in coliform bacteria by ethylenediaminetetraacetate. Journal of Biological Chemistry 243, 2373-2380.

LeIVE, L. (1974). The barrier function of the Gram-negative envelope. Annals of the New York Academy of Sciences 235, 109-127.

MARQUIS, R. E. (1968). Salt-induced contıaction of bacterial cell walls. Journal of Bacteriology 95, 775-78I.

NikaIDo, H. (1973). Biosynthesis and assembly of lipopolysaccharide and the outer membrane layer of Gram-negative cell wall. In Membranes and Walls of Bacteria, pp. I3I-208. Edited by L. Leive. New York: Marcel Dekker.

Rayman, M. K. \& MaCLfoD, R. A. (1975). Interaction of $\mathrm{Mg}^{2+}$ with peptidoglycan and its relation to the prevention of lysis of a marine pseudomonad. Journal of Bacteriology 122, 650-659.

ReYNolds, J. A. (1972). Are inorganic cations essential for the stability of biological membranes? Annals of the New York Academy of Sciences 195, 75-85.

Salton, M. R. J. (1964). The Bacterial Cell Wall, p. 246. Amsterdam: Elsevier. 